\title{
BREVES NO'TAS SOBRE A RESPONSABILIDADE PELAS DÍVIDAS CONTRAÍDAS POR UM DOS CONJUGES NO EXERCÍCIO DA ACTIVIDADE COMERCIAL *
}

Helena Salazar

\section{SUMÁRIO}

I. Introdução

II. A evoluçâo histórica do instituto

1. Código Civil de 1867

2. Código Comercial de 1888

3. Código Civil de 1966

4. Principais alterações resultantes da Reforma do Código Civil em 1977

5. Alterações resultantes da Reforma do Código de Processo Civil em 1995

III. O enquadramento actual das dividas contraídas por um dos conjuges no exercício da actividade comercial

1. Princípios gerais em matéria de dívidas conjugais

2. Referência ao regime de responsabilidade dos cônjuges face às outras dividas referidas nas demais alíneas do n." I do artigo 1691." do Código Civil

3. Análise da alínea d) do 17." I do artigo 1691. do Código Civil e do artigo 15." do Código Comercial: o regime das dívidas comerciais

3.1. Dívidas resultantes do exercício do comércio

3.2. Dívidas contraídas em proveito comum do casal

3.3. Não se encontrarem os conjuges casados sob o regime da separação de bens

4. Bens que respondem pelas dividas resultantes do exercício do comércio

5. Alterações resultantes da Reforma do Código de Processo Civil em 1995

IV. Conclusões

\section{Introdução}

Com a realização deste trabalho propomo-nos reflectir sobre um tema que interessa simultaneamente a dois ramos do direito, o direito da família e o direito comercial.

\footnotetext{
"Comunicação apresentada no âmbito das Comemorações dos 35 Anos do Código Civil, Direito da Família e das Sucessões, realizadas entre 24 e 26 de Outubro de 2002 , na Faculdade de Direito da Universidade de Coimbra.
} 
A protecção do comércio, aliada à protecção do credor, na prossecução da tutela do crédito, objectivo último do direito comercial, justifica a natureza excepcional do regime das dívidas comerciais; com efeito, as repercussões que este gera ao nível familiar tornam difícil o equilíbrio entre interesses familiares e mercantis. A convivência dos dois ramos do direito, e os interesses claramente antagónicos que lhes estão subjacentes - respectivamente assentes nos interesses da socicdade familiar e nos da proteç̧ão do credor - não tem sido fácil. $O$ regime das dívidas comerciais, aliás, suscitou sempre muitas dúvidas na doutrina e na jurisprudência. Tal aconteceu, de resto, noutras matérias como as da possibilidade de constituição de sociedades entre cônjuges'.

Apesar de amplamente analisada, esta questão tem sido alvo de um estudo mais aprofundado sob o ponto de vista do direito comercial do que do direito da família, pese embora a matéria das dívidas conjugais aparecer tratada na sua essência no Livro IV do Código Civil, permitindo-nos afirmar tratar-se de uma matéria do âmbito familiar.

Sendo este um tema que trataremos no âmbito do Congresso de Direito da Família e das Sucessões, onde se comemoram dos 35 anos do Código Civil e os 25 anos da Reforma de 1977, entendemos ser relevante uma breve referência à cvolução histórica do instituto das dívidas comerciais, possibilitando o enquadramento do tema. Em primeiro lugar, faremos uma referência ao regime consagrado no Código de Seabra, e o modo como este conviveu com o disposto no Código Comercial de 1888 que se the seguiu no tempo. Seguir-se-á a análise da versão original do Código Civil de 1966 e da sua articulação com o regime constante do Código Comercial, onde a matéria estava já tratada. Prosseguiremos fazendo uma análise do estado actual do problema, e das principais questões que resultam do texto legal e bem assim das que se colocam quer do ponto de vista doutrinário quer do ponto de vista jurisprudencial.

Com esta abordagem pretendemos justificar a necessidade de se prever, nesta matéria das dívidas dos cônjuges, um regime diferente daquele que resultaria da aplicação das regras gerais em matéria de dívidas, que constam, como se sabe, da parte geral do Código Civil, e cuja necessidade se fundamenta na comunhão de vida que o casamento

\footnotetext{
1 Neste sentido, Caciro (1986, p. 30)
} 
a todos os níveis determina, nomeadamente no que para aqui é relevante - os seus aspectos patrimoniais. De todo modo, convém referir que podendo esta matéria ser susceptível de diferentes abordagens, apenas nos iremos centrar na questão que pensamos ser essencial, analisando assim a responsabilidade de um cônjuge pelas dívidas contraídas pelo outro cônjuge no seu exercício do comércio em nome individual, e não de todos os aspectos do regime das dívidas conjugais constantes dos artigos $1690 .^{\circ}$ e seguintes do Código Civil. Nesta nossa análise, contudo, e sempre que considerarmos necessário, faremos referência às outras situações previstas no n. ${ }^{\circ} 1$ do artigo $1691 .{ }^{\circ}$ do Código Civil, nomeadamente para melhor compreensão e enquadramento do problema tratado.

A temática que trataremos coloca-se a dois níveis distintos, ambos de extrema importância, sendo que a resposta que for oferecida ao primeiro influencia claramente o seguinte. Num primeiro plano, e esta ć uma das notas de especialidade do regime, trataremos do apuramento da responsabilidade da dívida, que poderá vir a ser considerada da responsabilidade de um, ou de ambos os cônjuges. Aqui, no âmbito das dívidas familiares, e ao contrário das obrigações em geral, constatámos que não tem aplicação o princípio res inter alios acta relativamente a terceiros, já que o cônjuge que não contraiu nem deu o seu consentimento pode ser responsável pela dívida. O segundo ponto diz respeito aos bens que responderão por essa dívida da exclusiva responsabilidade de um dos cônjuges, ou de ambos, e aqui apontaremos uma outra especialidade que tem a ver com a regra da solidariedade. Esta regra não aparece aqui com as características gerais que the conhecemos, pois não se trata de solidariedade de devedores como encontramos em tantas outras situações, mas sim solidariedade de patrimónios, pois a comunhão conjugal exige regras diferentes.

Importa notar que trataremos apenas das dívidas contraídas por um dos cônjuges, sem o consentimento do outro, no exercício do comércio, ou seja das chamadas dívidas singulares que, aliás, são as mais problemáticas. Vigora nesta matéria da responsabilidade por dívidas dos cônjuges um princípio importante e que resulta do disposto no artigo $1692 .^{\circ}$, a saber, que cada cônjuge é, em princípio, responsável pelas dívidas que contrair sem o consentimento do outro. O tema que 
trataremos aparece como uma excepção a esta norma e princípio básico, pois tratando-se de uma dívida contraída por um cônjuge no exercício da sua actividade comercial, desde que o seja em proveito comum do casal, irá responsabilizar o outro cônjuge, isto se estivermos perante um dos regimes da comunhão de bens. Como a seu tempo referiremos, quando vigorar o regime da separação de bens entre os cônjuges, a questão tem, ao menos legalmente, tratamento diverso.

Analisaremos como se articulam as normas existentos actualmente no Código Civil e no Código Comercial de 1888, e de que forma foram atingidas pela Reforma do Código Civil cm 1977, e do Processo Civil em 1995. Apontaremos a eada passo as vantagens e desvantagens das alterações, assim como os efeitos práticos que se lhes seguiram.

Terminaremos o nosso trabalho apresentando breves conclusõcs $\mathrm{c}$ deixando algumas questöes em aberto, nomeadamente quanto à necessidade de manutenção deste regime em lace da existência de instrumentos de crédito tão eficazes e diversilicados, que podem atingir o mesmo objectivo de incremento e tutela do crédito que se visa acautelar. Sendo a divida oriunda do comércio de um dos cônjuges, e em proveito de ambos, fará sentido manter um regime diversilicado quando os conjuges apenas por serem casados no regime de separação de bens aquela apenas responsabilizará o conjuge que a contraiu? Quando os pressupostos são em tudo o mais idênticos, fará sentido manter a todo o custo esta independência patrimonial? E não deveria a dívida apenas responsabilizar o cônjuge que a contraiu, se garantissem o seu pagamento o património e os frutos do seu estabelecimento comercial?

\section{A evolução histórica do instituto}

\section{Código Civil de 1867}

Na regulamentação das dívidas dos cônjuges no âmbito do Código Civil de 1867, quando comparado com o regime actual, pode constatar-se desde logo uma característica essencial, e ao mesmo 
tempo uma diferença substancial no tratamento desta matéria, que nos permite afirmar que naquele texto estavam mais protegidos os interesses familiares. Com efeito, aquilo que no texto se encontrava regulado cra a responsabilidade dos cônjuges pelas dívidas em geral, não existindo quaisquer especialidades no texto da lei que determinassem solução diversa?

Nessa conformidade, no 2." parágrafo do artigo 1114." estatuía-se que as dívidas contraídas pelo marido, sem outorga da mulher, obrigavam os bens comuns se tivessem sido aplicadas em proveito comum dos cônjuges. Não se distinguiam, assim, as dívidas consoante a sua origem, sendo o factor determinante da comunicabilidade a sua aplicação em proveito comum do casal, conceito que viria a ser um dos mais tratados pela doutrina e pela jurisprudênciat.

Ainda no âmbito de vigência deste Código, alguns anos mais tarde, em 1888, o Código Comercial viria a considerar que se presumiam aplicadas em proveito comum as dívidas comerciais do marido comerciantes, sendo portanto, em regra, comunicáveis excepto se a mulher ilidisse aquela presunção".

Ao contrário do Código Civil actual que, logo na redacẹão original, determinou soluçôes diversas em fimçăo da natureza da divida, privilegiando nomeadamente as resultantes do exercício do comércio.

"De notar que no âmbito deste Código, falava-se de proveito comum dos connjuges enquanto na lei actual fala-se cm proveito comum do casal. A mudança de expressão reve o sentido de reforçar a ideia de que o benefício há-de verificar-se em favor da sociedade conjugal; ou seja, da actual legislação resulta a ideia de unidade do casal como condição para a responsabilização de ambos.

"Como questöes essenciais em forno da aplicaçào deste conceito encontramos, em primeiro lugar, a de saber se o proveito comum era avaliado em lunção da finalidade ou dos resultados da contracção da divida, sendo que quer a doutrina, quer a jurisprudência, consideravam que se a feria pelo fỉm visado pela aplicaçẫo, e não pelo resultado; em segundo lugar, a de saber se o proveito comum tinha de resultar imediatamente do acto constitutivo, ou bastava que losse o resultado indirecto ou mediato, sendo que esta última ideia cra a que obtinha mais consagração.

Consagrando-se, assim, a primeira presunção de comercialidade das dividas resultantes do exercicio do comércio.

"De salientar que na vigencia deste Código era o marido o administrador dos bens da mulher e do casal, sendo a mulher incapaz para contrair quaisquer dividas, adquirir o alienar bens e exercer o comércio sem o consentimento do marido. 
Daqui parece resultar que as duas normas, o 2..$^{\circ}$ parágrafo do artigo 1114." do Código Civil c o artigo 15." do Código Comercial, encaixavam perfeitamente, pois na lei civil o determinante era o proveito comum e da lei comercial resultava a presunção especificamente aplicável a estas dívidas -- isto apesar de, cm geral, o regime das dívidas no âmbito deste Código ter sido considerado das matérias mais obscuras c das que levantaram mais dúvidas entre a doutrina?

\section{Código Comercial de $\mathbf{1 8 8 8}$}

Na redacção original do Código Comercial era possível encontrar duas normas que tratavam da disciplina das dívidas comerciais. Foi com o aparecimento deste Código que nasceu e ganhou acuidade a questão da conciliação dos interesses familiares com os interesses mercantis; assim, em benefício do comércio e dos fins por cle perseguidos, estabeleceu-se um regime especial que sacrificou os interesses familiares $\mathrm{cm}$ função dos mercantis, conforme resultava dos artigos 10. e 15.".

A primeira norma que na sistemática do Código tratou desta matćria foi o artigo $10{ }^{\circ}$ onde se estatuiu que o pagamento das dívidas comerciais do marido que tiver sido feito pela meação dele nos bens comuns, pode ser exigido antes de dissolvido o matrimónio ou de haver separação, sendo porém a mulher citada para, querendo, pedir a separação judicial de bens no decénio posterior à penhora.

A par deste, o artigo 15." estipulava que as dívidas provenientes de actos comerciais contraídas só pelo marido comerciante, sem outorga da mulher, presumir-se-ão aplicadas em proveito comum dos cônjuges ${ }^{8}$. Este é um dos aspectos que nos permite concluir pela predominância mercantil desta questão, já que ao estabelecer um regime de protecção às dívidas resultantes da actividade comercial, o Código Comercial dava conta das preocupações dos credores dos comerciantes.

\footnotetext{
${ }^{7}$ Neste sentido, Pires de Lima e Antunes Varela (1992, p. 324). Faz-se notar ainda que, atenta a complexidade da questão, surgiram vários Assentos do STJ.

" $\Lambda$ este propósito escreveu Lopes Cardoso (1968, p. 114) ser este o único caso que consagra uma presunção legal de proveito comum face à lei vigente nesta época.
} 
As normas tinham, como se verifica, campos de aplicação distintos. Com efeito a primeira norma referida, o artigo 10.\%, aplicava-se sempre que a dívida fosse da exclusiva responsabilidade do marido comerciante, enquanto a segunda, o artigo $15 .^{\circ}$, dizia respeito às dívidas comunicáveis.

$O$ regime tinha de ser articulado com o que a este respeito dispunha o Código Civil de Seabra, nomeadamente no 2." parágrafo do seu artigo $1114 .^{\circ}$, já por nós referido no ponto anterior, e do qual sobressaía a ideia de que as dívidas contraídas pelo marido responsabilizavam os bens comuns se tivessem sido aplicadas em proveito comum dos cônjuges.

Do ponto de vista da construção legal este parecia ser o regime perfeito. Com efeito, da lei civil resultava o critério geral para verificar a comunicabilidade, o proveito comum do casal, e da lei comercial, nomeadamente do artigo $15 .^{\circ}$, resultava o regime de privilégio que o Código estabclecia para as suas dívidas - as dívidas comerciais.

Em conclusão, qualquer dívida comercial ou civil se não fosse contraída $\mathrm{cm}$ proveito comum dos cônjuges jamais poderia responsabilizar o outro membro do casal.

\section{Código Civil de 1966}

O Código Civil de 1966", ao estabelecer novo regime, procurou resolver muitas das difíceis questões que no âmbito da legislação anterior se tinham colocado, apesar de na nossa análise termos constatado que foi no âmbito deste Código que surgiram algumas das mais importantes querelas doutrinárias nesta matéria, e que conduziram também ao aparecimento de vários Assentos, uns na vigência da redacção original do Código, outros já depois da Reforma de que o texto foi alvo em 1977.

Desde logo podemos notar uma alteração na terminologia utilizada, abandonando-se a referência à expressão "dividas comunicáveis" para adoptar o conceito de "dívidas da responsabilidade

\footnotetext{
9 Para um mais profundo conhecimento do regime vigente e dos aspectos mais relevantes suscitados na sua aplicação vide, entre outros, Lopes Cardoso (1968).
} 
de ambos os cônjuges"'". Na versão original do Código Civil, o artigo 1691. ${ }^{\circ}$ estatúa que são da responsabilidade de ambos os cônjuges, para além de outras, as constantes da alínea d), a qual dispunha que cram da responsabilidade de ambos os cônjuges "as dívidas contraídas por qualquer dos cônjuges no exercício do comércio, salvo se vigorar entre cles o regime da separação de bens".

Resulta do exposto que as dívidas resultantes da actividade comercial de um dos cônjuges eram sempre da responsabilidade do outro, excepto se entre eles vigorasse o regime da separação de bens, não existindo nenhuma referência em relação à necessidade do proveito comum do casal; desta forma, a dívida cra sempre comunicável.

Como a matéria do proveito comum dos cônjuges estava agora regulada no Código Civil, parte da doutrina considerava que estava tacitamente revogado o artigo 15." do Código Comercial". Com efeito, este regime agora inserido no Código Civil veio reforçar ainda mais a ideia já patente naquele artigo 15." do Código Comercial (que cronologicamente o antecedeu) e que, na perspectiva da protecção dos credores mercantis, estabelecia uma presunção de proveito comum relativamente às dívidas contraídas pelo marido comerciante sem o consentimento da mulher, ao dispor que "as dívidas provenientes de actos comerciais contraídas só pelo marido comerciante, sem outorga da mulher, presumir-se-ão aplicadas $\mathrm{cm}$ proveito comum dos cônjuges".

\footnotetext{
"O abandono desta terminologia tem essencialmente a ver com ideia errada que o uso da expressão poderia incutir de que estas dívidas existiam apenas nos regimes da comunhão, isto porque, vigorando o regime da separação de bens, podem existir dívidas que responsabilizam ambos os cônjuges e isto apesar de não existirem bens comuns.

"Sobre esta matéria, nomeadamente sobre a necessidade e utilidade deste artigo 15.", surgiram posições contraditórias. Lopes Cardoso (1968, p. 409), defendeu tratar-se de uma revogação parcial; por seu lado, Pinto Furtado (1984, pp. 77-78) considerou a norma de utilidade duvidosa, assumindo uma posição crílica quanto à articulação com o Código Civil; já Lobo Xavier (1977), Pupo Correia (1997) e Antunes Varela (1992), consideraram que esta norma serve essencialmente para dispensar o credor de fazer a prova de que a dívida resulta do exercício do comércio do devedor.
} 
Acresce ainda que, conjugadas as duas disposições do Código Civil e do Código Comercial, e visto que o Código Civil não faz agora qualquer referência ao marido ou à mulher, a norma passa a aplicarse a ambos os cônjuges, o que constitui uma novidade relativamente ao estatuído anteriormente no artigo 15. .

Também se apresenta como inovador nesta disposição do Código Civil de 1966 a alteração dos pressupostos de aplicabilidade da norma. Como já referimos, enquanto no regime precedente, constante do Código Civil de 1867, para que houvesse comunicabilidade da dívida bastava que a mesma resultasse de um acto de comércio, com o Código de 1966 não se mostra suficiente resultar a dívida de um acto de comércio, pelo contrário ela tem de ser contraída no exercício do comércio ${ }^{12}$. Do que afirmamos conclui-se que uma dívida contraída nestas circunstâncias, ou seja no exercício do comércio, inevitavelmente era da responsabilidade do casal, visto que não se dava ao cônjuge do comerciante a possibilidade de provar o contrário.

Pelas dívidas contraídas nos termos precedentes respondiam os bens comuns do casal, e na falta ou insuficiência deles, solidariamente os bens próprios de qualquer dos cônjuges, conforme resultava do disposto no $1 .^{\circ} 1$ do artigo $1695 .^{\circ}$, excepto se vigorasse o regime da separação de bens. Se, pelo contrário, a dívida fosse da exclusiva responsabilidade de um dos cônjuges, aplicava-se o artigo $1696 .^{\circ}$ do Código Civil. Este artigo consagrava a chamada regra da moratória, ao estabelecer que pelas dívidas da exclusiva responsabilidade de um dos cônjuges respondem os seus bens próprios e, subsidiariamente, a sua meação nos bens comuns. Mas, quanto a estes últimos bens, eles só respondem depois de dissolvido o casamento ou de decretada a separação de bens entre cônjuges. Como se constata, este regime traduzia o necessário equilíbrio dos interesses mercantis e familiares, não impedindo que o credor nomeasse desde logo à penhora a meação do devedor nos bens comuns, sendo que a execução da mesma só se efectivava depois

${ }^{12}$ Como refere Damas (1988, p. 197), o sentido desta expressão também não era unanimemente considerado na doutrina, questionando-se essencialmente se na protecção da norma também cabiam os actos de comércio ocasionalmente praticados. 
de dissolvido o casamento ou decretada a separação de bens ${ }^{13}$.

A justificar o instituto da moratória estava a ideia base de que os bens comuns estavam afectados à satisfação dos interesses comuns do casal e da família em geral, e como tal não deviam responder por dívidas da responsabilidade de um deles. Se é verdade que esta regra condicionava a cobrança dos créditos, nas circunstâncias descritas, não ć menos verdade que em relação a algumas dívidas não era necessário ao credor aguardar pela verificação de algum daqueles factos, nomeadamente porque esta regra conhecia excepções de que daremos conta mais tarde.

\section{Principais alterações resultantes da Reforma do Código Civil em 1977}

Como é sabido a Reforma de $1977^{14}$ introduziu importantes alterações no âmbito do Direito da Família, sendo que a matéria das dívidas também não foi excepção.

Interessa-nos especificamente na economia do presente trabalho analisar as alterações ao nível da matéria das dívidas comerciais, e por isso devemos desde já referir que as repercussões desta profunda Reforma determinaram também a alteração do artigo $15 .^{\circ}$ do Código Comercial.

As alterações foram produzidas pelo Decreto-Lei n. ${ }^{\circ} 496 / 77$ de 25 de Novembro no que ao Código Civil respeita, e pelo Decreto-Lei n. ${ }^{\circ}$ $363 / 77$ de 2 de Setembro quanto ao Código Comercial. Convém então referir, no que a este Código respcita que a matéria continuou tratada nos artigos 1690." e seguintes, dos quais para o nosso estudo destacamos os artigos 1691.', 1695. e 1696.․ No que concerne ao

\footnotetext{
13 A propósito da aplicação do artigo 10." do Código Comercial quando estavam em causa dívidas cambiárias punha-se a questão de saber se para se efectivar a responsabilidade do património comum era suficiente fazer a prova da comercialidade formal da dívida ou, pelo contrário, era necessário a prova da comercialidade substancial. A maior parte da doutrina defendia a necessidade desta última prova como requisito de comunicabilidade.

${ }^{14}$ Sobre os aspectos mais relevantes da Reforma nesta matéria vide, entre outros, Lobo Xavier (1977).
} 
Código Comercial a matéria aparece também, à semelhança do direito anterior, nos artigos 10. e 15.'. Assim, e mesmo antes de sabermos o sentido das alterações e bem assim a amplitude dos efeitos, a existência de uma Reforma deixa antever substanciais mudanças.

Subjacente à alteração do regime do Código de 1966 esteve essencialmente a necessidade de estabelecer um regime mais justo e ao mesmo tempo mais adequado ao interesse dos cônjuges e que continuasse a servir os interesses mercantis, já que como notamos no texto original havia uma clara desproporção de interesses.

Desde $\operatorname{logo}$, a solução introduzida agora pela Reforma apresenta-se como mais justa para o conjuge, porquanto permite que este afaste o proveito comum, mas mais insegura para os credores do comerciante. Com efeito, passa a resultar da alínea d) do n." 1 do artigo 1691." que quer no regime da comunhão geral, quer no regime de comunhão de adquiridos, as dívidas contraídas por qualquer dos cônjuges no exercício do comércio são da responsabilidade de ambos desde que contraídas em proveito comum do casal, excepcionando-se assim apenas o regime matrimonial da separação de bens.

Do texto da lei resulta uma presunção relativa quanto a estas dívidas contraídas no exercício do comércio, pois aquelas só não responsabilizarão ambos os cônjuges se se provar que não foram contraídas em proveito comum do casal, resultando do exposto, como se vê, a maior justiça do regime. Esta presunção passa a ser, como ainda hoje o é, um ponto de equilíbrio em que os interesses familiares cedem aos mercantis ${ }^{15}$.

É por demais óbvio, que do ponto vista do credor do comerciante, a solução agora consagrada se apresenta menos favorável do que no regime anterior, mas do ponto de vista dos interesses familiares a solução é de longe mais equilibrada e justa e correspondeu, de resto, a posições já anteriormente defendidas pela doutrina.

Genericamente, podemos considerar que o regime consagrado

\footnotetext{
${ }^{15}$ Lobo Xavier (1977, p. 243) considera que são muito poucos os casos em que não se pode falar da existência de proveito comum, "pois o normal é que o comércio do cônjuge (casado num dos regimes da comunhão) scja exercido com vista a granjear proveitos a aplicar em beneficio da família".
} 
nesta alínea d) do n." I do artigo 1691.0 tem em vista o alargamento das garantias patrimoniais do credor do conjuge comerciante, estabelecendo porém alguns limites que protegem o cônjuge não comerciante quanto à lutura responsabilização de ambos, nomeadamente se estes provarem que a dívida não foi contraída $\mathrm{cm}$ proveito comum do casal. Com efeito consagra-se aqui uma inversão do ónus da prova em favor da tutela dos interesses do comerciante, sendo que no caso em análise é o conjuge que tem interesse em provar das duas uma, ou que a dívida não é comercial, ou, sendo comercial, não foi contraída no interesse comum do casal ${ }^{16}$. $\Lambda$ ssim, doravante, passou a considerar-se que as dívidas contraídas no exercício do comércio só seriam da responsabilidade de ambos os cônjuges se se verilicassem estes requisitos.

Após as alterações introduzidas em 1977 torna-se facilmente evidente a diferença de regime das dívidas comerciais relativamente aos demais casos de dívidas conjugais contraídas por um dos conjuges sem o consentimento do outro; de facto, mesmo sem sairmos do n." 1 do artigo 1691." do Código Civil, deparano-nos com outros casos de dívidas que sendo contraídas por um dos conjuges responsabilizam ambos, e que tem aplicabilidade independentemente do regime de bens (de comunhão ou de separação) adoptado pelos cônjuges.

Já no que concerne às alterações introduzidas em 1977 no artigo 15." do Código Comercial constata-se que se passou a estabelecer uma presunção iuris tantum, cujo objectivo final é a inversão do ónus da prova, partindo-se do pressuposto de que a maior parte das dívidas dos comerciantes se ligam ao exercício do seu comércio, o que, aliás, ainda hoje se mantém, já que se estabelece que "as dívidas comerciais do conjuge comerciante presumem-se contraídas no exercício do comércio".

O conteúdo desta norma vem novamente $\mathrm{em}$ reforço da defesa do credor do comerciante, pois este, ao intentar uma acção contra o

\footnotetext{
"De notar que algumas destas questòes serão retomadas e desenvolvidas adiante quando tratarmos a situação actual do problema, pelo que nos limitamos nesta parte a levintar as questôes mais relevantes que se suscitaram na aplicação do regime. Também não é demais referir que este regime introduzido pela Reforma de 1977 é em grande parte acpuele que se encontra em vigor.
} 
devedor comerciante, não tem de provar que a dívida resulta do exercício da aclividade comercial, bastando alegar e provar que a dévida resulta de um aclo de comércio. Será o próprio comerciante ou o seu cônjuge que terão interesse em demonstrar que a divida, embora comercial, não resulta do excrécio do comércio, logo o credor não poderá beneficiar desta presunção, nem a dívida cabcrá por csse facto na alínea d) do n." I do artigo 1691." do Código Civil.

Na sequência, dependendo da verificação dos requisitos por nós brevemente enunciados, a divida scrá da responsabilidade de ambos os cônjuges, e neste caso responderào por cla os bens referidos no artigo 1695." do Código Civil, cuja epígrafe é "dívidas da responsabilidade de ambos os conjuges". Neste caso, respondem os bens comuns do casal, e, na falta ou insuficiência deles, solidariamente, os bens próprios de qualquer um dos cônjuges. Já o n." 2 desta norma esclarece que quando a dívida for da responsabilidade de ambos, mas vigorar entre eles o regime da separação de bens, a responsabilidade não é solidária.

Quando pelo contrário, ou porque se provou que a dívida não resultou do exercício do comércio ou porque sendo comercial provou-se que nào foi contraída $\mathrm{em}$ proveito comum do casal, a dívida, de acordo com o princípio geral nesta matéria, é da responsabilidade exclusiva do cônjuge que a contraiu, respondendo por cla os bens constantes do artigo 1696." do Código Civil, que no seu n." I estabeleceu que pelas dívidas da exclusiva responsabilidade de um dos cônjuges respondem os seus bens próprios e, subsidiariamente, a sua meação nos bens comuns, estabelecendo-sc que quando fossem chamados estes últimos o pagamento só se efectivaria depois de dissolvido o casamento ou decretada a separaçăo de bens entre os cônjuges.

Fixa-se, então, a denominada regra da moratória, cujo objeclivo era o de garantir a subsistência do acervo patrimonial comum dos cônjuges que, perante dívidas da responsabilidade de um, não deveriam ser afectados. Esta regra da moratória definia um regime diverso consoante a natureza da dívida. E neste contexto que o artigo 10." do Código Comercial passou a dispor depois da Reforma que "não há lugar à moratória estabelecida no n." I do artigo 1696." do Código 
Civil quando for exigido de qualquer dos cônjuges o cumprimento de uma obrigação emergente de acto de comércio, ainda que este o seja apenas cm relação a uma das partes"17. Face ao exposto podia concluir-se que alguns créditos tinham tratamento privilegiado pelo legislador porquanto não precisavam de aguardar a dissolução do casamento, como acontecia com as dívidas comerciais supra referidas.

Como se sabe o regime da moratória foi revogado pelo DecretoLei n." 329-A/95 de 12 de Dezembro que aprovou significativas alterações ao Código de Processo Civil, e não há hoje, por esse instituto, senão interesse histórico. Ao terminar com este regime acabou-se também com muitas querelas doutrinárias resultantes da sua aplicação.

\section{Alterações resultantes da Reforma do Código de Processo Civil em 1995}

A moratória que cra justificada, como atrás se referiu, pela cstabilidade do património comum, foi eliminada pelo Decreto-Lei

\footnotetext{
${ }^{17}$ Relativamente a este artigo levantaram-se inúmeras dúvidas que se prendiam sobretudo com a articulação do seu regime com o artigo $15^{\circ}$ do Código Comercial e os artigos 1691." e 1696." do Código Civil, nomeadamente porque se a dívida coubesse no artigo 1691.", n." I, alínea d), em conjugação com o artigo 15." do Código Comercial, açuela era da responsabilidade de ambos os cônjuges, e como tal não haveria lugar à aplicação do regime do artigo 10." do Código Comercial, só assim não acontecendo se o cônjuge ilidisse a presunção de que a dívida não resultava do exercício do comércio. Por outro lado, falava-se de dívida resultante de acto de comércio, sendo que também se disculiu largamente que tipos de acto de comércio estavam contemplados na norma: objectivos, subjectivos, formais, substanciais, unilaterais e bilaterais.

Suscitava-se ainda no domínio deste artigo o tratamento da questão das dívidas tituladas por letras, nomeadamente a necessidade da prova da comercialidade substancial da dívida assim como sobre quem recaía esse ónus. A este propósito o STJ no Assento $4 / 78$ de 13 de Abril, na esteira do anterior Assento de 27/11/64, considerou que este artigo só se aplicava quando existisse uma dívida proveniente de um acto de coméreio substancialmente comercial. Esperava-se que na Reforma se tivesse tomado posição sobre esta matéria, o que não veio a acontecer. Tendo este último Assento resolvido definitivamente a questão ao considerar que só está livre da moratória estabelecida no n." 1 do artigo $16960^{\circ}$ do Código Civil, se mesmo no domínio das relações mediatas estiver provada a comercialidade substancial da dívida exequenda.
} 
n. $329-\mathrm{A} / 95$ de 12 de Dezembro, que aprovou o Código do Processo Civil. Até aqui podia ler-se no n. ${ }^{\circ}$ I do artigo $1696 .^{\circ}$ que pelas dívidas da responsabilidade de um dos cônjuges respondiam os bens próprios do cônjuge devedor e, subsidiariamente, a sua meação nos bens comuns, e acrescentava-se que "neste caso, porém, o cumprimento só é exigível depois de dissolvido, declarado nulo ou anutado o casamento, ou depois de decretada a separação judicial de pessoas e bens ou a simples separação judicial de bens". Do regime geral da moratória e da regra aqui estatuída, conclui-se claramente pela proteç̧ão dos interesses familiares, mas as excepções que admitia quanto a certas dívidas constantes do $\mathrm{n}^{\circ} 3$ do artigo $1696 .^{\circ} \mathrm{e}$ no artigo $10 .^{\circ}$ do Código Comercial, se concluía que face a certos interesses, nomeadamente quando a dívida resultasse do excrcício do comércio, os interesses familiares cediam perante aqueles.

Ao suprimir-se a segunda parte do n." 1 e o n. 3 do artigo 1696.", deixa de fazer sentido o artigo $10{ }^{\circ}$ Código Comercial, logo pode-se concluir que o legislador acabou definitivamente com o regime da moratória, solução que foi aplaudida pelos comercialistas que encaravam a moratória como um obstáculo à satisfação dos interesses dos credores em geral - isto porque os credores do comerciante já estavam protegidos pela excepção do artigo $10^{\circ}$ do Código Comercial's.

As explicações acerca da extinção do regime da moratória, nomeadamente as que se encontram no preâmbulo do Código são escassas, no entanto todas se centram na mesma ideia, a de que o regime da moratória era injustificado. A contribuir para a extinção deste privilégio parecem ter estado razões essencialmente de ordem prática como o acesso desproporcionado ao crédito e o consequente endividamento dos particulares, por exemplo através da proliferação e facilidade do acesso ao crédito ao consumo, a cartões de crédito, ao desconto de letras, ctc., que aparentemente determinou o incremento do número de famílias completamente sobrecarregadas e insolventes. E também razões de índole processual, já que se constatava que a moratória amiúde servia para impedir o credor de chegar à efectiva

\footnotetext{
${ }^{18}$ Contra a moratória já se havia pronunciado Pinto furtado (1984, pp. 33-34).
} 
execução do pagamento da dívida, e ao mesmo tempo demonstrava a desproporção face à excessiva protecção da família quando comparada com a protecção dos comerciantes ${ }^{14}$.

\section{O enquadramento actual das dívidas contraídas por um dos cônjuges no exercício da actividade comercial}

\section{Princípios gerais em matéria de dívidas conjugais}

Antes de passarmos à análise do regime tal como ele se nos apresenta hoje, iremos referir brevemente alguns princípios que $\mathrm{em}$ matéria de dívidas são essenciais para tornar esta matéria inteligível.

No artigo 1690." do Código Civil está consagrado o princípio segundo o qual cada um dos cônjuges tem legitimidade para contrair dívidas, civis ou comerciais, sem o consentimento do outro ${ }^{20}$. Este é aliás, o princípio com que abre a Secção II do IX Capítulo do Código Civil a propósito dos efeitos do casamento, e que já se encontrava no Código de 1966, embora tenha sido a Reforma de 1977 que the imprimiu os contornos que hoje the conhecemos, estabelecendo definitivamente e sem limites uma igualdade de ambos os cônjuges em matéria de legitimidade para contrair dívidas.

Um outro princípio importante nesta matéria é o que está consagrado no n. 2 deste artigo $1690 .^{\circ}$. Aqui estabelece-se a regra do momento relevante para apurar a responsabilidade, nomeadamente se esta dívida foi contraída anteriormente ao casamento. Este momento é fixado tendo em consideração a data do facto que deu origem à dívida. Não há dúvidas quanto à necessidade e relevância da norma já que, com efeito, da sua aplicação pode ficar estabelecido de imediato de quem é a responsabilidade por determinada dívida.

Quanto ao disposto no artigo $1692 .^{\circ}$ resulta a regra geral do regime

\footnotetext{
19 É tendo por base esta ideia que Almeida Garrett (1998, p. 71) considera ter o legislador civil sacrificado a tutela da família do devedor em função da protecção do credor, também ele tantas vezes um comerciante.

${ }^{20}$ Este princípio é o corolário da igualdade de direitos e deveres na orientação da vida em comum e da família, e que está consagrado no artigo 1671. ${ }^{\circ}$ do Código Civil.
} 
das dívidas dos cônjuges. Em princípio, a dívida contraída por um dos cônjuges é da sua inteira responsabilidade, independentemente do regime de bens, salvo se se tratar de dívidas especialmente excepcionadas nas alíneas b) e c) do n." I do artigo 1691.", ou seja, aquelas dívidas contraidas antes ou depois do casamento para fazer face aos encargos normais da vida familiar ou contraídas pelo cônjuge administrador em proveito comum do casal, caso em que poderão ser da responsabilidade de ambos. Do que se acaba de referir resulta então que há no artigo $1691 .^{\circ}$ um regime especial de responsabilidade do outro cônjuge pelas dívidas que só um deles contraia ${ }^{21}$.

Para melhor compreendermos os contornos e as especificidades das dívidas conjugais que constituem o cerne deste estudo torna-se essencial que analisemos, ainda que brevemente, o restante regime que em matéria de dívidas da responsabilidade de ambos os cônjuges que consta deste artigo $1691 .^{\circ}$ do Código Civil para podermos de seguida concluir as especialidades do regime das dívidas comerciais.

\section{Referência ao regime de responsabilidade dos cônjuges face às outras dívidas referidas nas demais alíneas do $n .{ }^{\circ} 1$ do artigo 1691." do Código Civil}

$\mathrm{O}$ artigo 1691." refere-se às dívidas que responsabilizam ambos os cônjuges, independentemente do regime de bens em que são casados.

O primeiro núcleo de dívidas conjugais a que se refere este artigo ć aquele que consta da alínea a) do n. ${ }^{\circ} 1$ que trata das dívidas contraídas pelos dois conjuges antes ou depois do casamento ou por um com o consentimento do outro. Quanto a estas dívidas, porque são contraídas simultaneamente pelos dois cônjuges ou por um com o consentimento do outro, não se levantam especiais problemas.

$\mathrm{Na}$ alínea b) do mesmo número surgem tratadas as dívidas contraídas por qualquer dos cônjuges, antes ou depois do casamento,

\footnotetext{
2 No artigo $1692{ }^{\circ}$ encontram-se ainda nas alíneas b) e c) outras dívidas que são da exclusiva responsabilidade de um dos connuges: as que provierem de crimes ou factos imputáveis a um dos cônjuges e as que resultarem de dívidas que oncram bens certos e determinados, nos termos do n." 2 do artigo $1694 . "$
} 
para ocorrer aos encargos normais da vida familiar, estabelecendo-se aqui a responsabilidade de ambos os cônjuges. Escondido na sua aparente simplicidade, este é um dos conceitos mais difícil de preencher, já que o legislador não deixou qualquer indicação ao intérprete do que deve considerar-se aqui abrangido, tendo o conceito sido inteiramente preenchido pela doutrina e pela jurisprudência ${ }^{22}$. Assim, e segundo nos ensina a doutrina, e em especial PereIrA Coflho e Guilhlrme de Oliveira (2001), cabem neste conceito as dívidas de pequeno valor relativamente ao padrão de vida do casal, dívidas correntes ou periódicas que cada um dos cônjuges tem de ser livre de contrair ${ }^{3}$. Tem sido o padrão de vida do casal que tem scrvido de critćrio para se aferir se a obrigação assumida por um dos membros do casal constitui ou não um encargo normal para aquela família ${ }^{24}$.

$\mathrm{Na}$ alínea c) aparecem tratadas como podendo ser da responsabilidade de ambos os cônjuges as dívidas contraídas pelo cônjuge administrador, dentro dos scus poderes e em proveito comum do casal. Aqui apenas se prevê a comunicabilidade das dívidas contraídas na constância do casamento; com efeito, é com o casamento que adquire relevo o instituto da administração de cada uma das massas patrimoniais daí em diante existente, sejam estas bens próprios ou bens comuns do casal. Assim, verificados determinados requisitos, uma dívida contraída pelo cônjuge administrador responsabilizará o outro cônjuge. Ora, as regras da administração são as que resultam dos artigos 1678." e seguintes do Código Civil. Como regras gerais vigentes em matéria de administração de bens, podemos dizer que cada

\footnotetext{
2 Sobre o preenchimento deste conceito, vide em especial o Acórdão do Supremo Tribunal de Justiça de 27 de Junho de 2000), CJ, II, Ano VIII, pp. 130-135.

2: É possivel encontrar alguns exemplos que traduzem a aplicação deste conceito, nomeadamente: o pagamento de uma operação de um fïho, o pagamento das férias de um tilho, o pagamento da festa do casamento e a viagem de núpcias, e, em geral, as dividas genéricas e comuns com vista à alimentação, vestuário, renda da casa, aquisição de combustível para o automóvel, elc.

${ }^{24}$ Este conceito não se confunde com o de proveito comum do casal que aparece aflorado na alínca seguinte, porque estes encargos podem dizer respeito apenas a um dos membros do casal, ou até a um filho, e não deixam por essc facto de responsabilizar os dois cônjuges.
} 
um dos cônjuges administra os scus bens próprios e que ambos administram os bens comuns, conforme os n. ${ }^{\circ}$ s 1, 2 e 3 do artigo 1678. .

Resolvida a questão de saber quem detém a administração, e para aplicar esta alínea c) do artigo 1691.", é agora necessário saber se o acto que originou a dívida cabe dentro dos poderes de administração daquele que o praticou ou se, pelo contrário, extravasa aqueles poderes e como tal é da responsabilidade do cônjuge que a contraiu. Como é sabido, no âmbito da relação matrimonial os poderes de administração são mais amplos do que os poderes de administração de bens alheios, cabendo aqui a prática de todos os actos de gestão do património relativamente aos quais não se exija o consentimento do outro cônjuge, o que dificulta a tarefa do intérprete ${ }^{25}$.

Finalmente, exige-se que a dívida contraída o seja em proveito comum do casal, isto é, que aquela tenha tido em vista o interesse de ambos os cônjuges ou da sociedade familiar. $\dot{E}$, pois, determinante saber se o administrador teve em vista um fim comum ou se procurou realizar um interesse única e exclusivamente seu, pois só assim se poderá concluir pela responsabilidade de ambos ou de apenas aquele que a contraiu.

Uma outra ideia importante quanto à aplicação do conceito resulta do disposto no n." 3 deste artigo 1691." onde se estabelece que o proveito comum não se presume, excepto nos casos em que a lei o declarar ${ }^{26}$. Esta regra, que à primeira vista não parece revestir grande importância, vai determinar que o credor ao demandar os conjuges tenha alegar e provar que aquela dívida foi contraída em proveito de ambos, caso contrário não conseguirá responsabilizar os dois membros do casal. Esta é, de resto, a principal diferença entre as alíneas b) e c) e a alínea d), que estabelece o regime das dívidas resultantes do exercício do comércio e que, por ser o tema central desta nossa reflexão, merece tratamento singular.

\footnotetext{
* Estão assim excluídos da aplicação da regra geral, por exemplo, a alienação de móveis pertencentes exclusivamente ao cônjuge que os não administra, excepto se se tratar de actos de administração ordinária e a alienação de móveis conjuntamente utilizados na vida do lar ou como instrumento comum de trabalho, como estatui o artigo 1682.", n." 3, alíneas a) e b).

". Um desses casos é certamente aquele a que nos referiremos quando analisarmos a alínea seguinte deste artigo, bem como o disposto no artigo $15 .^{\circ}$ do Código Comercial.
} 


\section{Análise da alínea d) do n." 1 do artigo 1691." do Código Civil e do artigo 15." do Código Comercial: o regime das dívidas comerciais}

A alínca d) consagra, como se sabc, a matćria das dívidas em que o nosso estudo assenta, o que nos permite afirmar que as obrigaçoes comerciais determinam a aplicação de um regime especial no que toca à responsabilização dos conjuges.

Cumpre desde já relevar que poderão responsabilizar ambos os cônjuges as dividas contraídas por um deles no exercício do comércio, ainda que sem o consentimento do outro". Esta é a primeira indicação que se colhe da leitura do artigo. Resulta do regime a clara intenção de beneficiar os credores do comerciante, pois sendo este casado pode no exercício da sua actividade mercantil responsabilizar o património comum por estas dívidas.

A questão tem sido alvo de controversa discussão, considerando uns que a dívida deve responsabilizar ambos os conjuges desde que exista proveito comum, outros que a dívida é da exclusiva responsabilidade do conjuge que a contraiu independentemente da existência de proveito comum (isto se forem casados no regime da comunhão de adquiridos) $\mathrm{e}$ admitindo outros que a solução mais justa passa pela responsabilização do cônjuge que contrai as dívidas, desde que tratada legalmente de forma diferente a questão dos frutos gerados no exercício do comérción.

Vamos analisar agora cada um dos requisitos legais para que se verifique a comunicabilidade destas dividas.

\footnotetext{
"As dividas de que aqui se trata especificamente são dividas contrádas pelo cônjuge que é comerciante, no exercício do seu coméreio, e sen o consentimento do outro, pois as contraídas pelos dois cônjuges caen no âmbito da alínca a).

" Com efeito, se os mesmos passassem a ser considerados bens próprios e não bens comuns, nestes casos seria diminuído o risco económico do exercício do comércio na medida em que se conlinava aquele excrécio ao património e aos rendimentos gerados, como hoje resulta da aplicação do n." 2 do artigo 1733." por remissão da alínea d) do n." I do 1699." do Código Civil que abrange lodos os regimes de bens. Neste sentido Pereita Coelho e Oliveira (2001, pp. 416).
} 


\subsection{Dívidas resultantes do exercício do comércio}

A primeira indicação que resulta desta alínea é a de que apenas cabem aqui as dívidas resultantes do exercício do comércio e não como noutros tempos se discutiu as dívidas resultantes da prática de actos de comércio ${ }^{311}$.

Como se sabe, subjacente ao exercício do comércio está a aquisição da qualidade de comerciante, a qual é adquirida pelas pessoas físicas que tendo capacidade para praticar actos de comércio, fazem destes profíssão". De acordo com o n." I do artigo 13." do Código Comercial está subjacente a esta categoria, em primeiro lugar, a capacidade para praticar actos de comércio ${ }^{32} \mathrm{e}$, em segundo lugar, a profissionalidade associada a essa prálica ${ }^{33}$, isto é, a prática forma regular, habitual e sistemática de actos de comércio no âmbito de uma das actividades que o legislador considera comerciais ${ }^{3+}$. Apesar de não

\footnotetext{
"A primeira questào que há a salientar é a do porquê de um regime especial apenas para o sector comercial; porque nâo a sua consagraçào para a indústria e para o exercício das prolissoes liberais?

"A diferença essencial reside no campo de aplicaçào da norma e também quanto às dívidas abrangidas pela disposiçào. De facto, se se considerassem da responsabilidade de ambos os cônjuges as dívidas resultantes da prática de quaisquer actos de coméreio seria muito mais amplo o campo de aplicação do artigo. Não loi este, como se sabe, o objectivo da norma, sendo que o que se pretende proteger é não a prática de actos de comércio, isolados, ocasionais, mas sim a sua prática associada ao exercício da profissào de comerciante.

"Neste sentido o Acórdão do Supremo Tribunal de Justiça de I de Julho de 1993, CJ, II, Ano l, pp. 178-180.

: A capacidade comercial ou seja a capacidade para praticar actos de comércio afere-se segundo o disposto no artigo 7." do Código Comercial que, por sua vez, atribui capacidade comercial àqueles que tiverem capacidade para o exercício de direitos nos termos da lei civil.

3 Quer-se com isto dizer que não basta a prática de actos de comércio isolados ou ocasionais para se poder ser considerado comerciante, neste sentido, entre outros, Pupo Correia (1997, p. 188$)$.

"É o artigo 2." do Código Comercial que nos aponta quais são os actos de comércio, agrupando-os em duas categorias: objectivos e subjectivos. Os primeiros são os que se acham especialmente regulados no Código e portanto cuja comercialidade deriva dos especiais interesses que tutelam; já os subjectivos são todos os contratos e obrigaçôes dos comerciantes que não forem de natureza exclusivamente civil, e se o contrário do
} 
consagrado senão indirectamente no Código Comercial $^{35}$, a doutrina tem acrescentado aos requisitos do n." 1 do artigo 13. ${ }^{\circ}$ um outro requisito que se traduz na necessidade destes actos serem praticados em nome próprio e não por conta de outrém.

O regime da responsabilidade das dívidas comerciais completa-se actualmente apenas com o disposto no artigo $15 .^{\circ}$ do Código Comercial $^{36}$, segundo o qual as dívidas comerciais do conjuge comerciante presumem-se contraídas no exercício do comércio. Ora, apesar de à primeira vista não se vislumbrar qual a utilidade do preceito, ele tem-na de facto, senão vejamos. ${ }^{37}$ As dívidas comerciais são aquelas que derivam de um acto de comércio e qualquer pessoa pode praticar actos de comércio dos quais resultam dívidas comerciais, e isto sem exercer uma actividade comercial, ou, exercendo-a, praticando um acto completamente alhcio a csse exercício.

É aqui que se vislumbra, segundo pensamos, o interesse deste artigo do Código Comercial, e isto apesar da doutrina não ser unânime sobre a sua verdadeira utilidade. Na realidade, ao estatuir-se que as dívidas comerciais se presumem contraídas no exercício do coméreio estabelcce-se uma presunção que claramente bencficia o credor do comcrciante - assim, o credor que demanda o comerciante não necessita senão de provar que o devedor é comerciante e a dívida

próprio acto não resultar. Os actos subjacentes à aquisição da qualidade de comerciante são os objectivamente comerciais, pois os da segunda categoria pressupõem que quem os pratica seja já comerciante face à lei.

3. Nomeadamente quando o Código caracteriza determinadas categorias de sujeitos como os gerentes de comércio, os auxiliares e os caixciros-viajantes, conforme artigos 248.", 256." e 257.". Não os considera comerciantes pois são meros mandatários comerciais, actuando em representação do comerciante para quem trabalham.

${ }^{36} \mathrm{E}$ isto porque o artigo $10 . \%$, que antes também tratava do problema, foi revogado em $1995 \mathrm{com}$ a entrada em vigor do novo Código de Processo Civil.

${ }^{37}$ A par do artigo 1691, n." I, alínea d), este artigo tem sido apontado como uma outra norma que protege os interesses mercantis. O seu principal objectivo é dispensar o credor de fazer a prova de que a dívida foi contraída no exercício do comércio do comerciante, nomeadamente encontrando-se acuele matriculado, invocando a presunção do artigo 11." do Código do Registo Comercial. 
comercial $^{38}$, cabendo ao comerciante ou ao seu cônjuge afastar esta presunção, fazendo prova de que aquela dívida não resulta do exercício do seu comércio ou do seu cônjuge, consoante os casos.

$O$ que quer dizer que, se o comerciante afastar a presunção, provando que a dívida embora comercial não resulta do seu comércio, então não haverá possibilidade de o seu cônjuge e o património comum ser responsabilizado pela dívida, porque a alínea d) do n." 1 do artigo 1691. 'só se aplica, e este é o primeiro requisito, quando a dívida resultar do exercício do comércio ${ }^{39}$. Estc é, então, o primeiro patamar de defesa que o comerciante ou o seu cônjuge dispõem para impedir a responsabilização do património comum.

\subsection{Dívidas contraídas em proveito comum do casal}

O segundo requisito de que se faz depender a comunicabilidade da dívida é que a dívida além de resultante do exercício do comércio, o seja em proveito comum do casal.

Este requisito traduz o ponto de equilíbrio entre os interesses comerciais e familiares. A proteç̧ão do comércio cede sempre quando, em concreto, se conclua não existir proveito para o outro cônjuge. Esta alínea estabelece uma presunção legal de proveito comum que determina a inversão do ónus da prova, não se verificando aqui as regras gerais do ónus da prova segundo as quais cabe àquele que alega fazer a sua prova, como decorre do artigo $342 .{ }^{\circ}$, n." 1 , do Código Civil ${ }^{40}$.

\footnotetext{
3* Sobre a matéria da comercialidade da dívida e das implicações na repartição do ónus da prova, vide entre outros: Acórdão do Supremo Tribunal de Justiça de 23 de Março de 1993, Cl, 1l, Ano I, pp. 31-33; Acórdão do Supremo Tribunal de Justiça de 29 de Setembro de 1993, CJ, III, Ano 1, pp. 43-44; Acórdão do Supremo Tribunal de Justiça de 5 de Maio de 1994, CJ, II, Ano II, pp. 77-78; Acórdão da Relação do Porto de 26 de Maio de 1994, CJ, 11I, Ano XIX, pp. 221-222; Acórdão do Supremo Tribunal de Justiça de 19 de Março de 1998, C.J, I, Ano VI, pp. 142-143.

3. Sobre o que deve entender-se como conceito de dívida contraída no excrcício do comércio, vide Acórdão do STI, de 27 de Junho de 2000, CJ, II, Ano VIII, pp. 130-135. 40 Neste sentido vide os Acórdãos da Relação do Porto de 26 de Abril de 1993, CJ, II, Ano XVIII, pp. 220-222 e de 22 de Fevereiro de 1994, C., I, Ano 11, pp. 119-121.
} 
A diferença de regime é notória, já que no âmbito das alíneas b) e c) cabe ao credor provar que a dívida foi contraída em proveito comum do casal, enquanto que da alínea d) resulta que o credor não tem de provar a existência de proveito comum. Quem no âmbito desta rclação tem interesse em provar que a dívida não foi contraída em proveito comum do casal, e por isso não responsabiliza os dois cônjuges, é o cônjuge do comerciante ${ }^{41}$. A razão de ser da norma assenta na idcia de que há proveito comum para o outro cônjuge, na medida em que, em geral, os proventos auferidos no exercício da actividade comercial são utilizados no sustento e na satisfação de interesses comuns dos conjuges e da sua família.

Para se poder falar de proveito comum o essencial não ć o resultado da contracção da dívida, mas sim o fim que lhe presidiu, isto é, se a referida dívida tinha em vista o interesse comum do casal, independentemente do resultado a que conduziu. Acresee que o conceito de proveito comum pode não apresentar conteúdo puramente lucrativo ou cconómico, pode ser intelectual, moral ou espiritual ${ }^{42}$.

Uma outra questão que se tem discutido na doutrina sobre a aplicação deste conceito é a de saber se pode existir proveito comum quando os cônjuges se encontram separados de facto ${ }^{43}$. A este propósito a doutrina tem maioritariamente considerado que a separação de facto não permite desde logo, e a priori, afirmar a inexistência de proveito comum.

É claro que o proveito comum não se apresenta sempre da mesma maneira, umas vezes resulta directamente do acto que determinou o aparecimento da obrigação, e outras vezes cle não resulta senão

\footnotetext{
"Como se conclui, o credor do comerciante goza de uma dupla presunção, a do artigo 1691.", n." I, alínea d) e a do artigo 15." do Código Comercial. Presunções ilidíveis, ou relativas, e que cedem mediante a prova do contrário.

"2 Sobre esta matéria ver especialmente as consideraçôes tecidas por Lopes Cardoso (1986) e Lobo Xavier (1977).

4: Sobre esta matéria tratou o Acórdão da Relação de Coimbra de 9 de Novembro de 1993, CJ, Ano XVIII, V, pp. 29-32.
} 
indirectamente daquele acto. É nestes casos que as dificuldades se revelam acrescidas na aferição da existência do proveito comum ${ }^{44}$.

\subsection{Não se encontrarem os cônjuges casados sob o regime da separação de bens}

Uma outra condição de aplicabilidade deste regime é que os cônjuges não se encontrem casados sob o regime da separação de bens ${ }^{45}$.

Da análise do regime das dívidas, nomeadamente daquelas que podem responsabilizar ambos os cônjuges, e que constam deste artigo $1691 .^{\circ}$ que temos vindo a analisar, ressalta imediatamente o facto de na alínea d) se estabelecer que estas dívidas só são comunicáveis se os cônjuges forem casados num dos regimes de comunhão. O que afirmamos tem expressão quando o legislador ressalva "ou se vigorar entre os cônjuges o regime da separação de bens". Esta excepção não resulta de nenhuma outra alínea deste artigo ou norma nesta matéria, o que nos permite afirmar que ao consagrá-la no âmbito das dívidas resultantes do comércio, o legislador teve como intenção impedir a sua aplicação sempre que, para regular as suas relações patrimoniais, os cônjuges tivessem escolhido o regime de separação de bens.

A ideia essencial deste regime é, como se sabe, que cada um dos cônjuges mantém a titularidade dos seus bens não existindo bens comuns, ou seja assegura-se uma total independência de patrimónios ${ }^{46}$. Com efeito, o facto de não existirem bens comuns entre os cônjuges casados sob o regime da separação de bens não significa que não possam existir, como existem, nomeadamente nas demais alíneas do artigo em análise, dívidas comuns que resultam da comunhão de vida

\footnotetext{
${ }^{45}$ É o artigo $1735 .^{\circ}$ do Código Civil que estabelece as características do regime, resultando como principal e comparando com os demais regimes a inexistência de bens comuns.

${ }^{40}$ Segundo Lopes Cardoso (1986), existe uma autêntica separação de patrimónios, pelo que nenhuma divida resultante do comércio pode responsabilizar o outro cônjuge porque os patrimónios são separados, e porque neste caso não se pode falar em proveito comum.
} 
que entre eles se estabeleceu. Pensamos, contudo, não ser relevante para a classificação da dívida, e para aferir a responsabilidade que determina, o regime de bens que os cônjuges escolheram para o casamento, mas antes se o outro cônjuge de alguma forma beneficiou daquela dívida.

Pode-se então perguntar o que justificou a opção do legislador por tal regime, afastando a responsabilização de ambos, mesmo existindo proveito comum do casal. A razão pode prender-se com o intuito de garantir uma total independência patrimonial entre os cônjuges, mas tal será de difícil compreensão na hipótese de existir proveito comum, significando que a dívida do conjuge comerciante determinou benefícios para o outro cônjuge, mas aquela não será da sua responsabilidade apenas e só porque é casado segundo o regime da separação ${ }^{47}$. Isto leva-nos a constatar, além do mais, a existência de diferentes critérios fixados pelo legislador de acordo com o regime de bens vigente entre os cônjuges, o que parece conduzir a um tratamento desigual. Com efeito, se nos regimes da comunhão o critério determinante é o proveito comum do casal, no regime da separação é o da composição e independência das massas patrimoniais dos dois cônjuges.

Como se vê, o regime de bens do casamento nada tem a ver com o proveito comum dos cônjuges, pois ele, como provámos, tanto existe nos regimes de comunhão como nos de separação. Acresce ainda que se é a proteç̧ão do credor que justifica a comunicabilidade das dívidas resultantes do exercício do comćrcio, não se vê porque a dívida não se há-de comunicar quando os cônjuges são casados no regime da separação ${ }^{4:}$.

\footnotetext{
${ }^{17} \mathrm{Na}$ opinião de Almeida Garrett (1998, p. 198) a finalidade dos regimes de bens não justifica esta solução.

${ }^{4} \mathrm{O}$ regime tal como está pode determinar conluios entre cônjuges que tendo casado num dos regimes que não o da separação, e em virtude do princípio da imutabilidade do regime de bens, se divorciem apressadamente de modo a garantir em seu próprio benefício, e em claro prejuízo do credor, a integridade dos seus bens. Além de conduzir os comerciantes mais avisados a escolher desde logo o regime da separação de bens, sem outro intuito que não o da preservação do património conjugal e familiar.
} 
Em torno da aplicação desta norma têm-se levantado várias questões. Num primeiro nível as dúvidas levantadas prendem-se com a justiça deste regime relativamente aos casais que se encontram casados no regime da comunhão. Tal como pensamos, esta é também uma das questões fulcrais que resultam da aplicação da norma. De resto, há quem proponha ${ }^{49}$ que não podendo a dívida comercial, contraída em proveito comum do casal, ser comunicável pela aplicação desta norma, porque esbarraria no texto da lei, poder vir a mesma, e para manter a ideia de justiça e equidade na aplicação das normas legais, a responsabilizar o outro cônjuge pela aplicação da alínea c) do n. ${ }^{\circ} 1$ do artigo $1691 .^{\circ}$, ou seja, valorizando definitivamente o proveito comum do casal como elemento determinante para a comunicabilidade, solução à qual damos a nossa concordância, apesar de sabermos que a maior parte da doutrina considera não poder haver responsabilização do outro cônjuge quando vigorar o regime da separação de bens ${ }^{\text {so }}$.

O que traz isto de novo para o tema que tratamos? Embora se permita ao credor poder responsabilizar os dois membros do casal ao abrigo desta alínea, é este quem em última análise sai prejudicado pela aplicação do regime da alínea c), quando comparado com o da alínea d), e que tem a ver com a questão do ónus da prova. Com efeito, perante a alínea c) cabe ao credor provar que a dívida foi contraída pelo cônjuge administrador, dentro dos seus poderes de administração e em proveito comum do casal. lsto é, para obter a responsabilização do cônjuge do comerciante o credor tem de alegar e provar a existência do proveito comum. Se, pelo contrário, estivermos perante as dívidas resultantes do exercício do coméreio, ao eredor bastará alegar que a dívida é comercial, que esta presume-se contraída em proveito comum do casal, ou seja, não terá de provar o proveito comum, porque a lei presume-o.

\footnotetext{
49 Como Almeida Garrett (1998).

"Contra esta nossa ideia pode ler-se o Acórdão da Relação do Porto de 9 de Junho de 1998, CJ, III, Ano XXIII, pp. 192-194, onde em resumo se considerou que a alínea c) do n." I deste artigo só se aplica a comerciante se a divida não for contraida no exercício do comércio, e, quando for contraída nesse exercício, é aplicável a alínea d) desse n. ${ }^{\circ} 1$.
} 
Fista diferença, que aparenta ser pouco significativa, reveste-se de uma enorme importância na postura processual do credor, que como autor terá maior ou menor responsabilidade no desfecho da lide, e mais empenho (por vezes manifestamente difícil) no objectivo que persegue, ou scja, a cobrança do seu crédito.

Consideramos, por isso, ser viável a aplicação do regime da alínea c) às dívidas resultantes do exercício do comércio quando os cônjuges forem casados no regime da separação de bens desde que o credor prove os requisitos da alínca c) $)^{5}$. Contra esta posição que hoje defendemos, por entendermos ser a mais justa e equilibrada, manifestaram-se vários autores?. Acreditamos ser esta posição defensável porque além das razòes aduzidas que se prendem com a maior justiça do regime, não ficam ofendidos os princípios em que assenta o regime da comunicabilidade das dívidas, e permite ao credor, também ele tantas vezes um comerciante, não se sentir defraudado nas suas legítimas expectativas de obtenção da cobrança do seu crédito.

\section{Bens que respondem pelas dívidas resultantes do exercício do coméreio}

Para que possamos saber quais os bens que respondem por determinada dívida temos previamente de saber se se trata da responsabilidade exclusiva de um dos cônjuges ou se, pelo contrário, é da responsabilidade de ambos os cônjuges.

$\triangle$ este respeito temos de analisar o disposto nos artigos $1695 .^{\circ}$, que fixa as dívidas da responsabilidade de ambos os cônjuges e que se aplica a todos os regimes de bens, c $1696^{\circ}$, que estabelece os bens que respondem pelas dívidas da exclusiva responsabilidade de um dos cônjuges.

\footnotetext{
"A favor desta posição, Almeida Garrett (1998, p. 60), por considerar que o diferente tratamento assenta apenas no regime de casamento, sem atender aos bencfícios que usulruíam pelo exercício da actividade mercantil do conjuge comerciante, e ainda que a soluçâo promove a igualdade entre credores, principio caro do direito comercial e allorado em textos de direito comercial recentes, como por exemplo no artigo 2." do CPEREF.

"Pires de Lima e Antunes Varela (1992, p. 336); Lopes Cardoso (1986, p. 189); Damas $(1988$, pp. 189 e 194) e, mais recentemente, Pupo Correia (1997, p. 96).
} 
O artigo 1695." dispöe no n." I que pelas dividas da responsabilidade de ambos os cônjuges respondem os bens comuns do casal e, na falta ou insuliciência dos mesmos, solidariamente os bens próprios de qualquer um dos cônjuges. Esta solução é compreensível, pois sendo a responsabilidade de ambos os conjuges, respondem em primeiro plano os bens comuns e, na lalta ou insuficiencia deles, os bens próprios de qualquer dos conjuges. Esta solidariedade dos bens próprios de qualquer dos conjuges já é uma vantagem considerável para o credor ${ }^{3}$.

Ainda no mesmo artigo $1695 . "$ mas agora no seu 11." 2 , estabelecese que no regime de separação de bens, e sendo a dívida da responsabilidade de ambos os cônjuges, a responsabilidade não é solidária, a menos que os conjuges de forma voluntária se tenham obrigado como devedores solidários. Isto significa que quando for este o regime de bens, cada um deles responde apenas pela parte da divida que the compete, aplicando-se portanto as regras da conjunção"t.

No n." I do artigo 1696." consagra-se que os bens que respondem pelas dívidas da exclusiva responsabilidade de um dos conjuges são os bens próprios do conjuge devedor e, subsidiariamente, a sua meação nos bens comuns. Já no n." 2 prevê-se que ao mesmo tempo que os bens próprios do cônjuge devedor respondem em simultâneo, alínea a), os bens por ele levados para o casal ou posteriormente adquiridos a título gratuito, bem como os respectivos rendimentos, alínea b), o produto do seu trabalho e os scus direitos de autor, e por fim na alínea c), os bens sub-rogados no lugar dos referidos na alínea a).

De acordo com o alirmado anteriomente, e em função da situação em análise, a dívida ou é da responsabilidade de ambos os cônjuges, e aplicamos a primcira disposiçăo, ou a dívida é da exclusiva

\footnotetext{
"Trata-se aqui não de uma solidariedade de devedores, mas de uma solidariedade de patrimónios. Como considera Menezes Cordeiro (2001) este regime da solidariedade quando aplicado à matéria das dividas dos conjuges apresenta algumas subtilezas.

A principal diferença da dívida responsabilizar os dois conjuges no regime da separaçăo, ou num dos regimes da comunhăo, fem a ver com a questăo da solidariedade. que vigorando o regime da separaçào a responsabilidade nào é solidária, conforme o disposto no artigo 1696." n." 2 do Código Civil, o que significa que cada um deles responde pela parte da divida yue the compete.
} 
responsabilidade do cônjuge que o contraiu, e aplicamos a segunda disposição.

No âmbito destas dívidas resultantes do excrcício do comércio, podem como referimos, surgir várias hipóteses, que condicionam como se vê a classificação da dívida e a aplicação de uma ou outra norma e, por conseguinte, pode ser maior ou menor o leque de bens que pode ser afectado ao cumprimento da obrigação.

Uma primeira hipótesc, prende-se com o facto da dívida poder não ser contraída no exercício do comćrcio, isto porque o cônjuge do comerciante ou o próprio comerciante podem provar que, de facto, aquela dívida que se presumiu comercial pela aplicação do artigo 15." do Código Comercial não resultou da actividade profissional do seu cônjuge ou da sua própria actividade. Neste caso, concluiremos que a dívida é da responsabilidade do cônjuge que a contraiu e aplica-se o artigo 1696.".

A segunda hipótese que nos ocorre, e que determina a classificação da dívida como sendo responsabilidade exclusiva ou comum dos cônjuges, é ser aquela contraída no exercício do comércio mas não em proveito comum do casal. Aqui, como sabemos, beneficiando o credor da presunção de proveito comum pode o cônjuge do comerciante, que é quem tem nisso interesse, afastar a referida presunção provando que não beneficiou directa ou indirectamente da assunção daquela obrigação, e com isso tornar aquela dívida da exclusiva responsabilidade do seu cônjuge comerciante. Como em devido tempo referimos este é, aliás, o ponto em que cedem os interesses comerciais face aos familiares.

A terceira, e última, hipótese que se nos coloca é a de a dívida resultar do exercício do comércio, em proveito comum do casal, mas serem os cônjuges casados segundo o regime da separação de bens. Aqui, temos de considerar que pela aplicação da alínea d) a dívida seria da exelusiva responsabilidade do cônjuge que a contraiu. No entanto, e em consonância com o que referimos anteriormente, não estão ainda esgotadas as hipóteses de responsabilizar o outro cônjuge, pois entendemos que mesmo neste caso pode o credor obter o efeito desejado, ou seja a responsabilidade de ambos os cônjuges, se provar que se trata de uma dívida contraída pelo cônjuge administrador, 
dentro dos seus poderes de administração e em proveito comum do casal. Não conseguindo fazer esta prova, então sim podemos concluir que a dívida é da exclusiva responsabilidade do cônjuge comerciante, respondendo por ela os bens referidos no artigo $1696 .^{\circ 5}$.

Sendo a dívida resultante do excrcício do comércio, em geral, contraída em proveito comum do casal, perante o regime da comunhão de adquiridos ou da comunhão geral, e não sendo afastada nenhuma das presunções, a dívida será da responsabilidade de ambos os cônjuges. Mas mesmo perante o regime da separação de bens ainda assim poderá a mesma comunicar-se quando o credor provar a existência do proveito comum, nos termos da alínea c). Pensamos ser esta a melhor e mais justa interpretação face ao regime vigente, apcsar de retirar ao credor a protecção que beneficia nos regimes da comunhão - querendo este responsabilizar o outro cônjuge pelas dívidas comerciais do cônjuge comerciante deve fazer a prova da cxistência do proveito comum, esse sim verdadeiro critério aferidor da responsabilidade de um ou de ambos os cônjuges.

\section{Conclusões}

A análise que aqui deixamos permitiu-nos constatar que o regime das dívidas contraídas no exercício do comércio foi sujeito a diferente tratamento ao longo dos tempos, e que das normas resulta uma nem sempre fácil convivência dos interesses mercantis com os interesses familiares.

O regime das dívidas comerciais é um regime claramente especial, dentro da especialidade em que se traduz já a matéria das dívidas dos cônjuges. Isto mesmo revelam os direitos do credor quando a dívida resulta do exercício do comércio, caso em que beneficia de uma dupla presunção, a primeira constante do artigo $15 .^{\circ}$ do Código Comercial e que o isenta de fazer a prova de que a dívida resultou do exercício do comércio, e a segunda prevista na alínea d) do n. ${ }^{\circ} 1$ do artigo $1691 .^{\circ}$ do

\footnotetext{
${ }^{55}$ É isso que justifica a normal actuação da banca que, por forma a evitar a realização da prova da comercialidade da dívida, exige a vinculação inicial e simultânea de ambos os cônjuges em termos de solidariedade convencional.
} 
Código Civil, que o isenta de provar que a dívida resultou em proveito de ambos os cônjuges.

Acresce que, pela aplicação destas normas, o credor conseguirá afectar ao pagamento da dívida a maior massa de bens, que depende como ć óbvio da dívida ser da responsabilidade de ambos ou apenas de um dos cônjuges, conforme resulta da aplicação dos artigos $1695 .^{\circ} \mathrm{e}$ 1696. 'o Código Civil.

Esta situação não ocorrerá sc os cônjuges forem casados no regime da separação de bens, mesmo tendo existido beneficio para aquele cônjuge que não exerce o comércio, solução com a qual não podemos concordar e, por isso, defendemos a possibilidade de o credor, no âmbito da alínea c) do n. ${ }^{\circ} 1$ do artigo $1691 .^{\circ}$ do Código Civil, poder provar a existência do proveito comum e dessa forma também conseguir responsabilizar os dois membros do casal. Entendemos, assim, dever ser o proveito comum o critério decisivo na responsabilização do outro cônjuge.

Finalmente, deixamos acui duas questões. A primeira é a de se saber se hoje o regime das dívidas comerciais ainda realiza os propósitos para os quais foi concebido, nomeadamente o da protccção do crédito. Na prevalência de tantos e tão variados instrumentos de crédito, não cuidará o credor de obter a vinculação do cônjuge do comerciante casado, eliminando dessa forma dificuldades futuras ao nível da prova? Por último, e para resolver definitivamente este problema da responsabilidade do outro cônjuge e da afectação do seu património, porque não proceder à alteração do quadro legal, nomeadamente ao nível do tratamento dos frutos gerados no exercício da actividade comercial, e que são hoje bens comuns em todos os regimes de bens, atento o disposto no n. ${ }^{\circ} 2$ do artigo $1733 .^{\circ}$ do Código Civil? Não será de os considerar bens próprios, afectando-os pelo menos em primeira linha ao pagamento das dívidas resultantes no excrécício do comércio? 


\section{Bibliografia}

ALMFIDA (IARRETT, J. A. (1998) Dividas Comerciais. Revista Juridica da Universidade Portucalense Infante D. Henrique, Ano I, Junho, n." I, Porto

ANTUNES VARELA (1993)--Direito da Familia. Vol. I, 3." ed., Lisboa, Livraria Petrony

CAFIRO, António (1986) - Sobre a Participaçăo dos Conjuges em Socicdades por Quotas. Temas de Direito Comercial, Ciclo de Conferências no Conselho Distrital do Porto da Ordem dos Advogados, Coimbra, Livraria Almedina, pp. 27-63

CASTRO MLNDES, João de (1990/1) Dircilo da Familia. AAFDL, Lisboa

COUTINHO DE ABREU, Jorge Manuel (2000) ... Curso de Direito Comercial. Vol. I, 2." ed., Coimbra, Livraria Almediná

DAMAS, J. A. Domingues (1988)-Dividas Comerciais dos Conjuges (reflexos familiares). As Operações Comerciais, Coimbra, Livraria Almedina, pp. 183-240

FERRER CORREIA, A. (1973) ‥ Licôes de Direito Comercial. Vol. I, Coimbra, Universidade de Coimbra

LEITE DE CAMPOS, Diogo (1990) - Liçós de Direito da lamilia é das Sucessões. Coimbra, Livraria Almedina

LOBO XAVIER, Vasco da Gama (1977/8) - Direito Comercial. Sumários das Lições ao 3." ano Jurídico, Coimbra

LOBO X AVIER, Vasco da Gama (1977) - Responsabilidate dos Bens do Casal pelas Dividas Comerciais de Um dos Cônjuges. Revista de Direito e Estudos Sociais, ano XXIV, Out-Dez, n." 4, Coimbra, pp. 241-68

loPES CARDOSO, Augusto (1968) Algums Aspectos das Dividas dos Cônjuges no Novo Código Civit. Revista dos Tribunais, Porto, ano 86.", Fev., n." 1828. pp. 51-63, e Mar., n." 1829, pp. 99-114

LOPES CARDOSO, Augusto (1973) - A Administraçao dos Bens do Casal. Coimbra, Livraria $\wedge$ lmedina

LOPES CARDOSO, Augusto (1986) - Da Responsabilidade dos Conjuges por Dividas Comerciais. Temas de Direito da Familia, Ciclo de Conferencias no Conselho Distrital do Porto da Ordem dos Advogados, Coimbra, Livraria Almedina, pp. 165-208

MENEZES CORDEIRO, António (2001) - Manual de Direito Comerécial. Vol. I,

Coimbra Livraria Almedina

OLAVO, Fernando (1978) "- Dircito Comercial. Vol. I, 2." ed., 2." reimpr., Coimbra, Coimbra Editora

PEREIRA COELHO, Francisco; OLIVEIRA, Guilherme de (2001) -... Curso de Direito da Familia. Vol. 1, 2." ed., Coimbra, Coimbra Editora

PINTO FURTADO, J. (1984) - Disposiçós Gerais do Código Comerial. Coimbra, Livraria Almedina

PIRES DE LIMA; ANTUNES VARELA (1992) - Código (ivil Anotado. Vol. IV, 2." ed., Coimbra, Coimbra Editora 
PUPO CORREIA, Miguel J. A. (1997)-Direito Comercial. 5." Edição revista e actualizada, Lisboa, SPB Editores

SANCIÑENA ASURMENDI, Camino (1996) - Regimen Economico Matrimonial Del Comerciante, Dykinson 